\title{
CORPORATE GOVERNANCE AND CORPORATE SOCIAL RESPONSIBILITY SOCIETY DISCLOSURE: THE APPLICATION OF LEGITIMACY THEORY
}

\author{
Joanne Shaza Janang \\ Universiti Malaysia Sarawak \\ Corina Joseph* \\ Universiti Teknologi MARA \\ Roshima Said \\ Universiti Teknologi MARA
}

\begin{abstract}
It is important for companies to adhere to society's values by engaging in corporate social responsibility activities to remain legitimate, which in turn, translated into disclosures in annual reports. Corporate governance mechanisms have been used as explanatory factors in determining the level of disclosures. This paper aims to determine the influence of corporate governance mechanisms on the society disclosure in Malaysian companies' annual reports using the legitimacy theory. The level of society disclosure is examined against the Modified Society Disclosure Index (MoSDI), which was developed based on the society indicator of Global Reporting Initiative Version 4.0, preliminary observation on the 2016 NACRA winners' annual reports and past literature. The analysis involved 234 top Malaysian companies' annual reports from 2014 to 2016. The results found that audit committee, independent directors, and size are significantly associated with the level of society disclosure. By complying with good corporate governance practice, awareness can be raised and preventive measures can be taken in addressing society's issues through proper society disclosure. The legitimacy gap can be reduced via the society disclosure.
\end{abstract}

Keywords: Society disclosure; Legitimacy theory; Corporate governance ${ }^{1}$

\section{INTRODUCTION}

Corporate social responsibility (CSR) has become a global trend and this has marked an important area in literature. The growing evidence of CSR initiatives plays a significant role in promoting corporate reputation that has motivated companies around the globe to engage in CSR reporting (Othman, Darus, \& Arshad, 2011). Every company is committed to ensure that its corporate reputation is not tarnished (Stuebs \& Sun, 2015). Therefore, by engaging in CSR activities, companies can address society's issues and needs through adequate disclosures in their annual

\footnotetext{
* Corresponding author: Corina Joseph, Faculty of Accountancy, Universiti Teknologi MARA, Cawangan Sarawak, Malaysia. Email: corina@uitm.edu.my
} 
reports. Hence, CSR disclosures in annual reports are considered as a good communication tool for companies to report on CSR strategies to enhance their transparency and accountability towards affected stakeholders. Similarly, there have been numerous studies conducted to address issues and new updates on CSR (e.g. Abdul \& Ibrahim, 2002; Amran \& Devi, 2008).

Several efforts have been undertaken by the government to achieve sustainability, and one of them is by promoting and enhancing better CSR practices among listed companies in Malaysia. For instance, to nurture and enhance CSR practices in Malaysia, Bursa Malaysia's CSR Framework was introduced on 5 September 2006 (Securities Commission Malaysia, 2016), whereby this signifies that the government is committed in promoting CSR practices among PLCs in Malaysia, in which greater transparency can be achieved through disclosures in annual reports. However, there have been limited studies that specifically examine society disclosures reported in annual reports compared to other CSR disclosures, such as environmental disclosure (Cahaya \& Hanifa, 2016). Therefore, the focus of this paper is to address the research gap by examining the extent of society disclosures in Malaysia.

Research on society disclosure is important because, nowadays, companies perceive the society as one of their important stakeholders. According to Cahaya and Hanifa (2016), conflicts may arise if companies do not pay much attention to their surrounding neighbours, specifically the community, for example, lack of water supply (Sman, 2016). Hence, one of the ways to address these issues is through disclosures, where awareness can be raised and preventive measures can be taken.

The need to maintain a harmonious relationship between the firms and the society has triggered companies to disclose high quality CSR disclosures. This is because, businesses are trying their best to ensure that the stakeholders' trust is maintained (Stuebs \& Sun, 2015). Hence, corporate governance is believed to play an important role in ensuring that the CSR disclosures reported are high in quality, whereby they fulfil the society's needs and expectations. A study conducted by Habbash (2016) in Saudi Arabia found that corporate governance mechanism has a positive relationship with CSR disclosures.

Bhimani and Soonawalla (2005) argued that, corporate governance and CSR implementations within a corporation are equally important for companies to achieve sustainability. It is crucial that firms adopt the corporate governance mechanism to gain legitimacy (Biggart, 1991) through various CSR activities in order to reduce the legitimacy gap. The main purpose of firms adopting CSR is because they want to be socially accepted and seen as a legitimate entity by the affected stakeholders, such as the society. Hence, the society will have more confidence in the companies knowing that the CSR activities carried out by the firms are based on good corporate governance practices (Stuebs \& Sun, 2015). Dentchev (2004) also argued that CSR disclosure acts as a strategic tool for firms to be legitimate towards their stakeholders. Therefore, the aim of this study is to determine the influence of corporate governance mechanisms on the extent of society disclosure in Malaysian companies' annual reports using the legitimacy theory. 


\section{LITERATURE REVIEW}

\subsection{Corporate Social Responsibility and Society Disclosure}

The development of CSR in Malaysia started in 1970's (Anas, Rashid, \& Annuar, 2015). According to Teoh and Thong (1984), most previous CSR practices were not disclosed, and thus, CSR awareness and practices are still relatively low. Since the introduction of Bursa Malaysia's CSR Framework in 2006, the development of CSR in Malaysia is progressing. There has been multifarious research carried out to address issues on CSR (e.g. Abdul \& Ibrahim, 2002;) that provides more in-depth understanding and knowledge on the development of CSR in Malaysia.

Recent studies in Malaysia have focussed on new aspects of CSR reporting. A recent study by Joseph, Gunawan, Sawani, Rahmat, Noyem, and Darus (2016) found that the extent of CSR reporting on anti-corruption information disclosure and practices in Malaysia is still at its infant stage. A study by Midin, Joseph, and Mohamed (2017) found that there were low-level disclosures of stakeholder engagement information on the Malaysian local authorities' websites. As stakeholder engagement is a key part of CSR, it is important that private and public sectors receive feedback from stakeholders at all levels to improve decision making and accountability. This is because, according to Cahaya and Hanifa (2016), sustainability can be achieved if amity exists between an entity and the stakeholders.

Society disclosure is part of CSR disclosures. Cahaya and Hanifa (2016) viewed society disclosure as efforts undertaken by companies to disclose any activities on society, as well as their obligations and responsibilities in managing social impacts towards the society in which they are engaged in. In this globalized era, companies are disclosing more CSR related disclosures, especially on society disclosure to meet the society's demands.

The Global Reporting Initiative (GRI) also acknowledges the importance of society disclosure as part of CSR reporting. GRI provides relevant and up-to-date guidelines on specific standard disclosures, which comprise three main categories, namely, economic, environmental, and social categories (Global Reporting Initiative, 2016). Under the social category, there is one sub-category on society. This indicates that GRI is determined to address issues on society to help reporters effectively report on society disclosure. Moreover, GRI guidelines are recognised as the most widely accepted sustainability guidelines (Albareda, 2013). GRI G4 society guidelines comprise seven key aspects, which are community, corruption, public policy, anti-competitive behaviour, compliance, supplier assessment for impacts on society, and grievance mechanisms for impacts on society. As compared to GRI G3 society guidelines, which only comprise of five key aspects, GRI G4 society guidelines signify that disclosures on society are timely in today's globalized era as businesses are aware of the adverse impact of their operations towards the society.

In their study, Cahaya and Hanifa (2016) indicated that there was a low level of society disclosure, resulting in only $40.27 \%$ among the Indonesian Stock Exchange (IDX) listed companies. By employing the GRI G3 society disclosure items to examine society disclosure, Cahaya and Hanifa (2016) concluded that the highest items disclosed were those related to society's programs, i.e. 98.67\%. Despite the low level of society disclosure in Indonesia, Cahaya and Hanifa (2016) found that only company size was a positively significant predictor of society disclosure practices. 
Yekini, Adelopo, Andrikopoulos and Yekini (2015) examined the relationship between board independence and the quality of community disclosures in the annual reports of the United Kingdom (UK) listed companies. It was found that the frequency of audit committee meeting, the presence of CSR committee, and higher proportion of non-executive directors influenced the companies in the UK to disclose high quality corporate community involvement activity disclosures. This indicates that audit committee, CSR committee, and the presence of nonexecutive directors have acted as a good control mechanism in assisting companies to disclose fair and transparent CSR disclosures involving the community via adequate disclosures in annual reports. CSR in Indonesia and UK is progressing, especially in regards to society and corporate community involvement disclosures. However, the extent of society disclosure in Malaysia is still unknown and there is a need for more studies to be carried out in the country.

\subsection{Corporate Governance}

Corporate governance is where a company is governed by a set of systems, principles and processes, which provides appropriate guidelines on how the company should be directed to fulfil its objectives to achieve long-term goals (Thomson, 2009). Hence, corporate governance is important to ensure that organizations and companies adhere to strict laws and regulations to improve transparency and accountability of the existing systems. Without a good corporate governance system, it is difficult for a firm to achieve its long-term goals, and thus, this will jeopardise the firm's sustainability.

There are two types of corporate governance: internal and external (Gillan, 2006). Internal corporate governance serves as a controlled set of rules that monitors the progress of an organization to meet its internal objectives and goals; while external corporate governance is derived from outside of the corporation (Davoren, 2016). Therefore, to achieve good governance practices, both internal and external corporate governance mechanisms must be in an equilibrium state (Dharmastuti \& Wahyudi, 2013).

The revolution of corporate governance has evolved tremendously. Past corporate scandals, such as Enron marked an important journey towards corporate governance reformation. After the collapse of these scandals, corporate governance legislation and guidelines were introduced to forestall such scandals from happening again and to ameliorate corporate governance environment (Bhatt, 2016).

The Southeast Asian financial crisis in 1997 also contributed to corporate governance reformation. The Malaysian government had embarked on a series of governmental reforms to strengthen corporate governance practices in Malaysia. Prior to the financial crisis, Malaysia had already foreseen the importance of corporate governance. Hence, it is mandatory for PLCs to establish an audit committee as required by Kuala Lumpur Stock Exchange listing requirement under Section 334, with effect from $1^{\text {st }}$ August 1994 (Haniffa \& Hudaib, 2006), with the purpose to act as an internal control mechanism. In March 1998, Malaysian Institute of Corporate Governance (MICG) was established with the vision to be the leading advocate of corporate governance in Malaysia (Malaysian Institute of Corporate Governance, 2016).

In March 2000, Malaysian Code on Corporate Governance (MCCG) was established to promote and sustain a strong culture of corporate governance among PLCs. The MCCG code has marked a 
remarkable achievement in corporate governance reform in Malaysia. The reason behind this is that MCCG constantly revises its code to ensure that the code is up-to-date and reliable. It was initially revised in 2007 to strengthen the roles and responsibilities of the board of directors, the audit committee, and the internal audit function. Later, in 2012, the code was again revised, where the focus was on strengthening the board structure and composition by recognising the role of directors as active and responsible fiduciaries. A study by Bhatt (2016) concluded that there was a significant improvement in the performance of listed companies after the implementation of MCCG. This indicates that the corporate governance practice in Malaysia is relevant and at par with other developing countries.

\section{LEGITIMACY THEORY AND HYPOTHESES DEVELOPMENT}

\subsection{Legitimacy Theory}

Legitimacy theory is based on the notion of social contract that exists between an organization and the society in which it operates (Deegan \& Unerman, 2011). Under this theory, organizations are trying their best to be legitimate by operating within the bounds and norms of their respective societies (Khan, Muttakin, \& Siddiqui, 2013), whereby it is important for corporations to engage in socially responsible behaviour (O’Donovan, 2002).

The sustainability of firms is not jeopardized if the activities carried out are beneficial to the society. However, if the firms do not comply with the society's values and norms, legitimacy gap will arise. Legitimacy gap occurs when an imbalance exists between the organization and social values, where the perceptions of the society do not match the actions undertaken by the organization. Furthermore, Laan (2009) suggested that when the expectations of stakeholders and corporate performances do not match, this will lead to legitimacy gap. Therefore, it is important that the legitimacy gap is addressed to minimise the effect cause by these entities (Guthrie, Cuganesan, \& Ward, 2007).

Legitimacy gap can be addressed in various ways, for example, through legitimacy strategies (Guthrie, Cuganesan, \& Ward, 2007), such as CSR disclosures (Omran, 2015). As firms want to be viewed as a legitimate entity, disclosures in annual reports act as a good communication tool for the firms to promote better CSR practices. Moreover, corporations are engaging in CSR reporting because they want to get the approval from the society in order to remain sustainable (Omran, 2015). CSR activities can be implemented through charity dinners and fund raisings. By engaging in CSR activities, firms are serious in mitigating the downside of their business operation, and simultaneously, portraying their efforts to be legitimate towards the society (Omran, 2015).

\subsection{Hypotheses Development}

Most of the literature studied the attribute of corporate governance mechanisms in the area of CSR. However, only a few researchers had conducted studies on the relationship between corporate governance mechanisms and society disclosure. Therefore, this section discusses the relationship between the independent variables and the extent of society disclosure using the legitimacy theory in developing the following hypotheses. 


\subsubsection{Audit Committee}

Audit committee plays a fundamental role as part of corporate governance mechanism (Yekini et al., 2015). Audit committee improves and enhances corporate voluntary disclosures and is regarded as the significant corporate governance mechanism in ensuring that the social contract between the organization and society is not breached in order to minimise legitimacy gap (Akhtaruddin \& Haron, 2010). Prior studies have concluded that audit committee is significantly related to CSR and positively impacts the extent and quality of CSR reporting (e.g. Ho \& Wong, 2001; Khan et al., 2013). This signifies that audit committee helps firms disclose high quality CSR disclosures to stakeholders by assisting the management to plan better CSR strategies that meet society's expectations and needs, which is in line with the legitimacy theory. Hence, this will boost the society's confidence towards the firm, knowing that the firm's CSR activities are based on good corporate governance practices (Stuebs \& Sun, 2015). Therefore, it is hypothesized that:

H1: There is a positive relationship between the audit committee and society disclosure.

\subsubsection{CSR Committee}

CSR disclosures have been proven to benefit stakeholders at all levels by providing reliable and necessary information (e.g. Habbash, 2016; Ho \& Wong, 2001). Despite the extensive research on various CSR disclosures, Yekini et al. (2015) argued that there has been minimal research that examined the existence of CSR committee's impact on social disclosures. Furthermore, PetrovicLazarevic (2010) suggested that a board level CSR committee is needed to enhance the corporate governance structure to ensure that organizations adhere to the community's social values and norms, which is in line with the legitimacy theory.

The existence of CSR Committee acts as an excellent corporate governance tool because it will help the organization to strategize better CSR activities in meeting society's demands and needs, which in return, improving the firm's image as a legitimate entity. This will result in a harmonious relationship between the organization and the society, where social contract is maintained and the entity's value system is consistent with the value system of the larger social system (Lindblom, 1993). Therefore, it is hypothesized that:

$\mathrm{H} 2$ : There is a positive relationship between CSR committee and society disclosure.

\subsubsection{Board Size}

In every company, the existence of board of directors is significantly important. The board of directors plays a vital role in corporate governance process, where it acts as a monitoring and controlling mechanism to ensure that the organization's operation runs smoothly. For that reason, MCCG 2017 requires that at least half of the board members comprise independent directors (Malaysian Code on Corporate Governance, 2017) as compared to MCCG 2012, where the board should comprise a majority of independent directors, in which the chairman is not an independent director (NST Online, 2017). This indicates that boards with more independent directors act as a good corporate governance tool. Prior studies have proven that board size positively affects CSR disclosures (e.g. Jizi, Salama, Dixon, \& Stratling, 2014). Esa and Ghazali (2012) argued that larger board size enables the directors to discuss and exchange ideas. This will result in better decision 
making and improve the firm's image as a legitimate entity through better CSR strategies, which are then published in the company's annual reports. In line with the legitimacy theory, these CSR strategies enable the firm to legitimize its existence, and consequently, be accepted by the society (Heard \& Bolce, 1981). Therefore, it is hypothesized that:

H3: There is a positive relationship between board size and society disclosure.

\subsubsection{Independent Directors}

Independent directors are external directors that do not have material association with the company. They are considered as a good measure for corporate governance practices (Mallin, 2014) because they can monitor the management's activities to ensure that stakeholders' interests are well protected. According to Aburaya (2012), independent directors influence the managers to disclose high quality disclosures, such as CSR disclosures.

Independent directors have incentives to influence disclosure practices because they are concerned with maintaining their reputation, and thus, they effectively function as corporate governance mechanism in overseeing the firm's behaviour (Amran, Lee, \& Selvaraj, 2013). Therefore, companies that have more independent directors are able to exert greater influence on their management to implement better CSR strategies that meet society's needs and demands, where social contract is not breached and legitimacy can be maintained. Hence, independent directors act as a good corporate governance mechanism in monitoring the firm's activities as they are less closely involved in the daily business operations (Jizi et al., 2014) and possess the power to influence the board to disclose higher degree of accountability and transparency in CSR reporting (Amran et al., 2013). For this reason, it is hypothesized that:

H4: There is a positive relationship between independent directors and society disclosure.

\subsubsection{Control Variables}

This study considers three control variables, namely, size, leverage, and industry type, following the evidence identified by prior literature that has some influence on CSR reporting and disclosures (Habbash, 2016; Ghazali; 2007).

\section{RESEARCH DESIGN}

\subsection{The Sampling}

The sample frame for this study initially comprised 300 companies' annual reports, where top 100 listed companies in Bursa Malaysia from the years 2014, 2015 and 2016 were chosen as the samples. However, companies that are in the banking, financial, and investment sectors were excluded from the sample frame because these companies came separately under the Banking and Financial Institutions Act of 1989 (Rahman \& Ali, 2006). Companies with missing and incomplete annual reports were also excluded due to insufficient information for data collection process. 
Out of 100 companies' annual reports, 22 companies' annual reports were excluded, where only 78 companies' annual reports were analysed and examined. A final sample comprising 234 companies' annual reports in the years 2014, 2015 and 2016, measured by market capitalization were selected as the sample size, in which the annual reports for the year 2014 were used as the basis for selecting the top 78 listed companies in Bursa Malaysia.

\subsection{Content Analysis}

This study adopted the content analysis method to provide in-depth information related to the extent of society disclosure in Malaysia. According to Haniffa and Cooke (2005), the content analysis method has been commonly used in examining CSR disclosures. Krippendorff (1989, p. 403) defined content analysis as "a research technique for making replicable and valid inferences from data to their context". Past studies that adopted the content analysis method in examining CSR disclosures are Cahaya and Hanifa (2016), Midin et al. (2017), and Yekini et al. (2016). Thus, content analysis method was used in this study to examine the extent of society disclosure.

The primary unit of analysis is annual report since not all companies disclose their own stand-alone sustainability reports. Up to the point of this writing, there is no compulsory requirement by the government to prepare a stand-alone sustainability report. Therefore, it is more acceptable to analyse companies' annual reports as they publish their efforts in promoting better CSR practices that involve the society. This is because, annual reports provide thorough information on philanthropic CSR strategies that are mandatory for the companies listed in Bursa Malaysia to report on CSR activities in their annual reports after Bursa Malaysia's CSR Framework was introduced on 5 September 2006 (Securities Commission Malaysia, 2016). For that reason, annual reports are a reliable source of information as they contain the same level of disclosures reported in the stand-alone sustainability report.

\subsection{Dependent Variable}

The dependent variable in this study is society disclosure and the measurement technique used in this study is content analysis, which involves the examination of companies' annual reports. The level of society disclosure was examined against the Modified Society Disclosure Index (MoSDI), which was developed based on the society indicator of GRI Version 4.0, preliminary observation on the 2016 NACRA winners' annual reports and past literature. Overall, MoSDI comprises 50 items with 9 main categories. The extent of society disclosure was measured using unweighted disclosure index. In such measurement, each disclosure item was considered equally important, where a score of " 1 " will be awarded if the company reported on any information in regards to society disclosure and " 0 " if otherwise. This method is also known as the dichotomous coding (Khan et al., 2013). Therefore, MoSDI was developed by adding all the 50 items scored by each company and equally weighted.

\subsection{Independent Variables}

The measurement for independent variables is displayed in the Table 1 below. 
Table 1: Measurement of Independent Variables

\begin{tabular}{|c|c|c|c|}
\hline Variable & Measurement & $\begin{array}{l}\text { Type of } \\
\text { Variable }\end{array}$ & $\begin{array}{c}\text { Past Studies That Adopted } \\
\text { the Same Method }\end{array}$ \\
\hline $\begin{array}{l}\text { Audit } \\
\text { Committee }\end{array}$ & $\begin{array}{l}\text { Based on the total number of audit } \\
\text { committee members }\end{array}$ & Continuous & Said et al. (2009) \\
\hline CSR Committee & $\begin{array}{l}\text { "1" if the company has a CSR } \\
\text { committee, "0" if otherwise }\end{array}$ & Categorical & Yekini et al. (2015) \\
\hline Board Size & $\begin{array}{l}\text { Based on the total number of } \\
\text { directors seated on the board }\end{array}$ & Continuous & $\begin{array}{c}\text { Said et al. (2009), Yekini et } \\
\text { al. (2015) }\end{array}$ \\
\hline $\begin{array}{l}\text { Independent } \\
\text { Directors }\end{array}$ & $\begin{array}{l}\text { Based on the number of } \\
\text { independent directors to the total } \\
\text { directors on the board }\end{array}$ & Continuous & $\begin{array}{c}\text { Said et al. (2009), Habbash } \\
\text { (2016) }\end{array}$ \\
\hline
\end{tabular}

\subsection{Control Variables}

The control variables in this study are size, industry type, and leverage. Company size was measured based on the total assets of the company (Cahaya \& Hanifa, 2016; Zulkiflee, 2016). Industry type was measured dichotomously, whereby if the companies were in highly sensitive or controversial industry, "1" would be awarded and " 0 " if otherwise. Sensitive or controversial industries consist of the industries that are associated with highly visible social issues (Cai et al., 2012), such as increase of health problems and crime rate (Brammer \& Millington, 2005). To calculate the leverage, this study adopted the same method applied by Habbash (2016), where the total liabilities were divided by the total assets of the companies.

\section{ANALYSIS OF DATA}

This study employed Likelihood Ratio test, LSDV F-test, and Breusch Pagan LM test to reveal the significant variance of the unobserved fixed effects and autocorrelation issues resulted from fixed and random effects. These tests are important to decide whether the model is suitable for either pooled or panel regression. The results showed p-value was higher than 0.05 , implying that the model was appropriate for pooled regression. Therefore, this study did not employ fixed effect nor random effect. Instead, the study employed pooled regression under the scheme of hierarchical model. Hierarchical regression analysis was used to determine the influence of corporate governance mechanism on society disclosures in Malaysian companies' annual reports using the legitimacy theory. According to Petrocelli (2003), hierarchical regression analysis is a statistical method to test such specific, theory-based hypotheses.

Assumption tests were initially conducted before hierarchical regression analysis was carried out, i.e. test of linearity, normality, homoscedasticity, and multicollinearity to determine the appropriateness of the model. In testing the model, it involved two-fold, i.e. testing the individual control variables (Model 1), and testing the overall relationship after Model 2 estimation (Hair et al., 1998). The hierarchical regression Model 1 is as follows:

$\mathrm{SD}=\beta 0+\beta 5$ Tot Asset $+\beta 6 \mathrm{Lev}+\beta 7$ Industry $\mathrm{T}+\mathrm{e}$

The hierarchical regression Model 2 is as follows: 
$\mathrm{SD}=\beta 0+\beta 1$ AudCom $+\beta 2$ CSRCom $+\beta 3$ BoardS $+\beta 4$ IndDirec $+\beta 5$ TotAsset $+\beta 6$ Lev $+\beta 7$ Industry $\mathrm{T}+\mathrm{e}$

Where:

$\mathrm{SD}=$ Society disclosure

AudCom $=$ Audit committee

CSRCom $=$ CSR committee

BoardS $=$ Board size

IndDirec $=$ Independent directors

TotAsset $=$ Total asset

Lev $=$ Leverage

IndustryT = Industry type

$\beta=$ the coefficient of $x$, where how much $y$ changes for each one-unit change in $x$

$\mathrm{e}=$ error term

\section{FINDINGS}

\subsection{Descriptive statistics}

Table 2 provides the descriptive statistics for society disclosure (dependent variable) and continuous variables employed in this study, while Table 3 provides the frequency analysis for categorical variables in this study. As shown in Table 2, in average, the companies in Malaysia disclosed 17.3761 items out of 50 items. The item that was reported the most was on the Workplace category (97.44\%). Meanwhile, the items that were least disclosed were on the "Others" category $(0.43 \%)$ and the Stakeholder Engagement category $(0.43 \%)$.

Table 2: Descriptive Statistics for Society Disclosure and Continuous Variables

\begin{tabular}{lcccc}
\hline \hline \multicolumn{1}{c}{ Variables } & Minimum & Maximum & Mean & Std. Deviation \\
\hline Society Disclosure & 2.00 & 30.00 & 17.3761 & 5.88623 \\
Audit Committee & 3.00 & 6.00 & 3.5897 & 0.71949 \\
Board Size & 4.00 & 14.00 & 8.7308 & 1.77009 \\
Independent Directors & 2.00 & 8.00 & 4.1838 & 1.17758 \\
Size & 16.91 & 25.38 & 21.9993 & 1.34414 \\
Leverage & 0.00 & 0.91 & 0.2542 & 0.20520 \\
\hline \hline
\end{tabular}

Table 3: Frequency Analysis for Categorical Variables

\begin{tabular}{lcc}
\hline \multicolumn{3}{c}{ CSR Committee and Industry Type } \\
\hline & Frequency & Percent \\
\hline If CSR Committee do not present & 190 & 80.5 \\
If CSR Committee present & 44 & 18.6 \\
If not highly sensitive & 183 & 77.5 \\
If highly sensitive & 51 & 21.6 \\
\hline \hline
\end{tabular}


Table 3 above shows the frequency analysis for the categorical variables in this study, which are CSR committee and industry type. Based on the results, 44 companies have CSR committee $(18.6 \%)$; while for industry type, 51 companies are operating in highly sensitive industries $(21.6 \%)$.

\subsection{Multiple Regression Findings}

Table 4 indicates that the data were not normally distributed, where the skewness for total assets (company size) was 5.227, whereas the kurtosis was 34.477, in which both values were more than 2 , indicating that a transformation was necessary. Table 5 shows the results for skewness and kurtosis after transforming the total assets (company size) to normal scores. The test revealed that the data were normal, where the skewness value was within the range of +2 to -2 . According to George and Mallery (2003), the values of skewness and kurtosis that are within the range of +2 to -2 indicate that the data are normally distributed.

Table 4: Normality Test of Total Assets (Untransformed)

\begin{tabular}{lcccc}
\hline \multirow{2}{*}{\multicolumn{1}{c}{ Variables }} & \multicolumn{2}{c}{ Skewness } & \multicolumn{2}{c}{ Kurtosis } \\
\cline { 2 - 5 } & Statistic & Std. Error & Statistic & Std. Error \\
\hline Society Disclosure & -0.321 & 0.159 & -0.406 & 0.317 \\
Audit Committee & 1.076 & 0.159 & 0.766 & 0.317 \\
CSR Committee & 1.607 & 0.159 & 0.588 & 0.317 \\
Board Size & 0.443 & 0.159 & 0.506 & 0.317 \\
Independent Directors & 0.974 & 0.159 & 0.578 & 0.317 \\
Industry Type & 1.375 & 0.159 & -0.110 & 0.317 \\
Total Assets & 5.227 & 0.159 & 34.477 & 0.317 \\
Leverage & 0.756 & 0.159 & 0.482 & 0.317 \\
\hline \hline
\end{tabular}

Table 5: Normality Test of Total Assets (Transformed)

\begin{tabular}{lcccc}
\hline \multirow{2}{*}{\multicolumn{1}{c}{ Variables }} & \multicolumn{2}{c}{ Skewness } & \multicolumn{2}{c}{ Kurtosis } \\
\cline { 2 - 5 } & Statistic & Std. Error & Statistic & Std. Error \\
\hline Society Disclosure & -0.321 & 0.159 & -0.406 & 0.317 \\
Audit Committee & 1.076 & 0.159 & 0.766 & 0.317 \\
CSR Committee & 1.607 & 0.159 & 0.588 & 0.317 \\
Board Size & 0.443 & 0.159 & 0.506 & 0.317 \\
Independent Directors & 0.974 & 0.159 & 0.578 & 0.317 \\
Industry Type & 1.375 & 0.159 & -0.110 & 0.317 \\
Log Total Assets & -0.670 & 0.159 & 1.701 & 0.317 \\
Leverage & 0.756 & 0.159 & 0.482 & 0.317 \\
\hline \hline
\end{tabular}

Table 6 shows the correlation analysis between the dependent variable, independent variables, and control variables. The Pearson correlations coefficient reported in Table 6 found that there was no multicollinearity problem. According to Franke (2010), excessive collinear correlation or multicollinearity is often above 0.9. Based on Table 6, the Pearson Correlation value in each independent variable column revealed less than 0.9 , indicating that multicollinearity problem did not exist. 
Table 6: Correlation Analysis

\begin{tabular}{lccccccccc}
\hline \hline \multicolumn{10}{c}{ Correlations } \\
\hline SD & Pearson Correlation & 1 & $0.223^{* *}$ & -0.014 & $0.227^{* *}$ & $0.358^{* *}$ & -0.108 & $0.304^{* *}$ & 0.021 \\
AC & Pearson Correlation & $0.223^{* *}$ & 1 & $0.138^{*}$ & $0.240^{* *}$ & $0.363^{* *}$ & $0.201^{* *}$ & 0.082 & -0.014 \\
CSRC & Pearson Correlation & -0.014 & $0.138^{*}$ & 1 & $0.197^{* *}$ & $0.130^{*}$ & 0.117 & $0.158^{*}$ & 0.097 \\
BS & Pearson Correlation & $0.227^{* *}$ & $0.240^{* *}$ & $0.197^{* *}$ & 1 & $0.549^{* *}$ & 0.016 & $0.261^{* *}$ & $0.166^{*}$ \\
ID & Pearson Correlation & $0.358^{* *}$ & $0.363^{* *}$ & $0.130^{*}$ & $0.549^{* *}$ & 1 & -0.021 & $0.281^{* *}$ & $0.164^{*}$ \\
IT & Pearson Correlation & -0.108 & $0.201^{* *}$ & 0.117 & 0.016 & -0.021 & 1 & $-0.129^{*}$ & 0.052 \\
LTA & Pearson Correlation & $0.304^{* *}$ & 0.082 & $0.158^{*}$ & $0.261^{* *}$ & $0.281^{* *}$ & $-0.129^{*}$ & 1 & $0.324^{* *}$ \\
LEV & Pearson Correlation & 0.021 & -0.014 & 0.097 & $0.166^{*}$ & $0.164^{*}$ & 0.052 & $0.324^{* *}$ & 1 \\
\hline \hline
\end{tabular}

**. Correlation is significant at the 0.01 level (2-tailed).

*. Correlation is significant at the 0.05 level (2-tailed).

Table 7 displays the predictive power of this study, which comprises Model 1 (control variables and society disclosure) and Model 2 (that represents the model as a whole). Based on Table 7, the results showed that the adjusted $\mathrm{R}^{2}$ was $9.1 \%$, indicating that $9.1 \%$ variation of society disclosure can be explained by the control variables. In Model 2, the results in Table 7 showed that the adjusted $\mathrm{R}^{2}$ was $18.5 \%$, which indicates that the increase of $9.4 \%$ of society disclosure was explained by the corporate governance mechanisms. The significance level of this study was 0.01 . Based on Table 7, the p-value for both models was 0.000 . This means that the model is highly significant and indicates that the independent variables and control variables are able to predict the extent of society disclosure.

Table 7: Predictive Power of Model 1 and Model 2

\begin{tabular}{cccccc}
\hline \hline Model & P-value (Sig) & R & R Square & Adjusted R Square & $\begin{array}{c}\text { Std. Error of the } \\
\text { Estimate }\end{array}$ \\
\hline 1 & 0.000 & 0.320 & 0.103 & 0.091 & 5.61231 \\
2 & 0.000 & 0.457 & 0.209 & 0.185 & 5.31490 \\
\hline \hline
\end{tabular}

Table 8 presents the multiple regression results. Based on the results in Table 8 , in Model 1 , only company size measured by the total assets was having a highly significant relationship with the extent of society disclosure with p-value of 0.000 . Moreover, the coefficient $(+) 0.321$ revealed that there was a positive relationship between company size and the extent of society disclosure.

In Model 2, only size, independent directors, and audit committee revealed significant results. Based on Table 8, independent directors were highly significant at p-value of 0.001 , which was smaller than the 0.01 significance level, while audit committee was significant at p-value of 0.044 , which was smaller than 0.05 significance level. Therefore, the existence of an audit committee and independent directors was significantly associated with the extent of society disclosure. 
Table 8: Results of the Regression Analysis

\begin{tabular}{|c|c|c|c|c|c|c|}
\hline & \multirow[t]{2}{*}{ Model } & \multicolumn{2}{|c|}{ Unstandardized Coefficients } & \multirow{2}{*}{$\begin{array}{c}\text { Standardized } \\
\text { Coefficients }\end{array}$} & \multirow[t]{2}{*}{$\mathbf{t}$} & \multirow[t]{2}{*}{ Sig. } \\
\hline & & B & Std. Error & & & \\
\hline \multirow[t]{4}{*}{1} & (Constant) & -12.815 & 6.336 & & -2.023 & 0.044 \\
\hline & Log total assets & 1.408 & 0.293 & 0.321 & 4.810 & $0.000 * * *$ \\
\hline & Industry type & -0.883 & 0.901 & -0.062 & -0.981 & 0.328 \\
\hline & Leverage & -2.293 & 1.903 & -0.080 & -1.205 & 0.229 \\
\hline \multirow[t]{8}{*}{2} & (Constant) & -15.295 & 6.215 & & -2.461 & 0.015 \\
\hline & Log total assets & 1.087 & 0.290 & 0.248 & 3.751 & $0.000 * * *$ \\
\hline & Industry type & -1.171 & 0.883 & -0.082 & -1.326 & 0.186 \\
\hline & Leverage & -2.584 & 1.821 & -0.090 & -1.418 & 0.157 \\
\hline & Audit committee & 1.089 & 0.538 & 0.133 & 2.025 & $0.044 * *$ \\
\hline & CSR committee & -1.370 & 0.924 & -0.091 & -1.483 & 0.140 \\
\hline & Board size & 0.091 & 0.240 & 0.027 & 0.379 & 0.705 \\
\hline & Independent directors & 1.251 & 0.377 & 0.250 & 3.320 & $0.001 * * *$ \\
\hline
\end{tabular}

Notes: ***Highly significant at $\mathrm{p}$-value $<0.01$ level; **significant at $\mathrm{p}$-value $<0.05$; ${ }^{*}$ moderately significant at $\mathrm{p}$-value $<$ 0.1 level.

Table 9 presents the degree of freedom. Based on Table 9, the degree of freedom for Model 1 was 233, with mean square of 31.498. Meanwhile, for Model 2, the degree of freedom was 226, with mean square of 28.248 .

Table 9: Degree of Freedom for Model 1 and Model 2

\begin{tabular}{|c|c|c|c|c|c|c|}
\hline \multicolumn{7}{|c|}{ ANOVA } \\
\hline & Model & Sum of Squares & $\begin{array}{c}\text { Degree of } \\
\text { freedom (df) }\end{array}$ & Mean Square & $\mathbf{F}$ & Sig. \\
\hline \multirow[t]{3}{*}{1} & Regression & 828.352 & 3 & 276.117 & 8.766 & $0.000^{\mathrm{b}}$ \\
\hline & Residual & 7244.554 & 230 & 31.498 & & \\
\hline & Total & 8072.906 & 233 & & & \\
\hline \multirow[t]{3}{*}{2} & Regression & 1688.824 & 7 & 241.261 & 8.541 & $0.000^{c}$ \\
\hline & Residual & 6384.082 & 226 & 28.248 & & \\
\hline & Total & 8072.906 & 233 & & & \\
\hline
\end{tabular}

\section{DISCUSSIONS}

This paper aims to determine the influence of corporate governance mechanisms on society disclosure in Malaysian companies' annual reports using the legitimacy theory. Based on the results, it was found that the extent of society disclosure was relatively low $(34.75 \%)$, where in average, the companies in Malaysia disclosed 17.3761 items out of 50 items in the MoSDI. The item that was reported the most was on Workplace category $(97.44 \%)$, while the item that was least reported was on Stakeholder Engagement category (0.43\%) and "Others" category (0.43\%). A study by Cahaya and Hanifa (2016) revealed that there was relatively low level of society disclosure at $40.27 \%$ in Indonesia, where the highest level of communication was for issues related 
to society programs. Therefore, compared to Cahaya and Hanifa's (2016) findings, this study found that the extent of society disclosure in Malaysia was comparatively lower than in Indonesia.

The multiple regression results are presented in Table 8 and only audit committee, independent directors, and company size measured by the total assets were significantly related to the extent of society disclosure. The most significant variables that influenced society disclosure were company size and independent directors, where both variables were highly significant at 0.01 .

The presence of audit committee is a good control mechanism (Yekini et al., 2015) because it acts as an oversight function on firms' management. Therefore, based on the results in Table 8 , the existence of audit committee positively impacts the extent of society disclosure as audit committee help companies disclose high quality disclosure to the society, which is in line with legitimacy theory. Hence, this enhances society's trust towards the company, knowing that their CSR strategies are based on good corporate governance practices (Stuebs \& Sun, 2015). Moreover, as audit committee mainly comprises independent directors, it is able to influence the board to reduce the amount of information withheld (Ho \& Wong, 2001). It is important to ensure that the audit committee is effective and efficient in overseeing the corporate reporting practices (Akhtaruddin \& Haron, 2010). This also includes CSR reporting in annual reports to help the management come out with the right CSR strategies that meet society's information needs, where legitimacy gap can be addressed through legitimacy strategies and communicated via annual reports. Prior studies have also proven that audit committee plays an important role in CSR reporting (Ho \& Wong, 2001; Said et al., 2009). Hence, H1 is accepted.

Independent directors are a good measure for corporate governance practices (Mallin, 2014). Table 8 reports that the presence of independent directors influences the extent of society disclosure. The independent directors have the motivation to influence disclosure practices because they are concerned with their reputation. Therefore, they effectively function as corporate governance mechanism in overseeing firms' behaviour (Amran et al., 2013). Furthermore, independent directors do not engage in daily business operations and they are more neutral in nature (Jizi et al., 2014), in which they are able to give appropriate suggestions on ways to improve CSR strategies, especially on society disclosure. In line with the legitimacy theory, independent directors assist the board to strategize better society related activities to legitimize the company's presence that adheres to society's values and norms. Hence, H4 is accepted.

Company size measured by the total assets shows highly significant results, signifying that larger companies have more assets to invest heavily in society related activities. Due to visibility, firms are motivated to be more socially responsible as the adverse impact of business operations forces the firms to be legitimate towards affected stakeholders (Vurro \& Perrini, 2011). Hence, the companies that engage in CSR are trying to be legitimate, and simultaneously to survive in the society (Chu, Chatterjee, \& Brown, 2012).

Other corporate governance mechanisms (board size and CSR committee) did not significantly influence the extent of society disclosure. CSR committee was found to be an insignificant independent variable in explaining the extent of society disclosure in the Malaysian companies' annual reports because there was no mandatory regulation imposed by the government. According to Petrovic-Lazarevic (2010), a board level of CSR committee is needed to enhance and improve the corporate governance structure so that organizations adhere to community's social values, 
which is in line with the legitimacy theory as CSR committee will help the board specifically strategize activities involving the society. The insignificant results also indicate that the presence of a CSR committee in companies' management level was more to a voluntary effort, which the companies took to ensure that the CSR strategies were well planned and executed. Hence, it is understandable why the companies did not have their CSR committee as it was not a mandatory requirement. Therefore, $\mathrm{H} 2$ is rejected.

Board size was found to be insignificant in explaining the extent of society disclosure in the Malaysian companies' annual reports. A possible explanation for this is that companies with larger board size tend to disagree among themselves because larger board size has more directors with diverse educational backgrounds and experiences (Zahra \& Pearce, 1989). In the long run, it may lead to legitimacy problems, where companies are unable to address society's issues properly, and thus resulting in legitimacy gap. Furthermore, boards are generally inactive and only become active in the incidence of crisis (Jensen, 1993). Therefore, H3 is rejected. The overall results of the hypotheses are presented in Table 10.

Table 10: Summary of Hypotheses Development

\begin{tabular}{lclc}
\hline \hline \multicolumn{1}{c}{ Variables } & Hypothesis & \multicolumn{1}{c}{ Description } & \multicolumn{1}{c}{$\begin{array}{c}\text { Accepted/ } \\
\text { Rejected }\end{array}$} \\
\hline Audit committee & $\mathrm{H} 1$ & $\begin{array}{l}\text { There is a positive relationship between the audit } \\
\text { committee and society disclosure. } \\
\text { There is a positive relationship between CSR committee } \\
\text { and society disclosure. }\end{array}$ & Accepted \\
CSR committee & $\mathrm{H} 2$ & $\begin{array}{l}\text { There is a positive relationship between board size and } \\
\text { society disclosure. } \\
\text { There is a positive relationship between independent } \\
\text { directors and society disclosure. }\end{array}$ & Accepted \\
$\begin{array}{l}\text { Independent } \\
\text { directors }\end{array}$ & $\mathrm{H} 3$ & Rected \\
\hline \hline
\end{tabular}

\section{CONCLUSIONS}

The findings from this study contribute to a better understanding of the relationship between corporate governance and the extent of society disclosure as part of corporate social responsibility disclosure by adopting the legitimacy theory. It is concluded that the presence of audit committee and independent directors positively influences the extent of society disclosure in Malaysia. Larger companies are more motivated to be engaged in CSR because they are more visible in nature.

This study reflects on the three areas of research, which are corporate governance, corporate social responsibility society disclosure, and legitimacy theory. First, this study found that independent directors and audit committee were significantly associated with the extent of society disclosure, which indicates that corporate governance acts as a good monitoring tool to ensure that companies report on society disclosure in annual reports to provide in-depth society-based activities. Second, this study enhances the need for better society disclosure in annual reports as the results showed that the level of society disclosure was relatively low. It is crucial that companies report more on society disclosure to improve transparency and accountability that reflects their effort in 
legitimizing their existence. Third, this study indicates that legitimacy theory partially explains the influence of corporate governance mechanisms on the extent of society disclosure.

This paper is without limitations. First, this study adopted quantitative research design to determine the extent of society disclosures. Future research can examine the extent of society disclosure using other theories and corporate governance mechanisms to address the research gap. Future studies can also be conducted in other developing countries, such as Thailand. Secondly, this study primarily focused on top listed companies. Future studies could cover other units of analysis, for example, small and medium companies to obtain more insights on the society disclosure.

\section{REFERENCES}

Abdul, M. Z., \& Ibrahim, S. (2002). Executive and management attitudes towards corporate social responsibility in Malaysia. International Journal of Business in Society, 2(4), 10-16.

Aburaya, R. K. (2012). The relationship between corporate governance and environmental disclosure: The UK evidence (Doctoral thesis, Durham University, Durham). Retrieved from http://etheses.dur.ac.uk/3456/

Akhtaruddin, M., \& Haron, H. (2010). Board ownership, audit committees' effectiveness and corporate voluntary disclosures. Asian Review of Accounting, 18(1), 68 - 82.

Albareda, L. (2013). CSR governance innovation: Standard competition-collaboration dynamic. Corporate Governance, 13(5), 551-568.

Amran, A., \& Devi, S. S. (2008). The impact of government and foreign affiliate influence on corporate social reporting: The case of Malaysia. Managerial Auditing Journal, 23(4), 386- 404.

Amran, A., Lee, S., P., \& Selvaraj, S. (2013). The influence of governance structure and strategic corporate social responsibility toward sustainability reporting quality. Business Strategy and the Environment, 23(4), 217-235.

Anas, A., Rashid, H. M. A., \& Annuar, H. A. (2015). The effect of award on CSR disclosures in annual reports of Malaysian PLCs. Social Responsibility Journal, 11(4), 833-845.

Bhatt, P. R. (2016). Corporate governance in Malaysia: Has MCCG made a difference. International Journal of Law and Management, 58(4), 403-415.

Bhimani, A., \& Soonawalla, K. (2005). From conformance to performance: The corporate responsibilities continuum. Journal of Accounting and Public Policy, 24(3), 165-174.

Biggart, N. W. (1991). Explaining Asian economic organization: Toward a Weberian institutional perspective. Theory and Society, 20(2), 199-232.

Brammer, S., \& Millington, A. (2005). Corporate reputation and philanthropy: An empirical analysis. Journal of Business Ethics, 61(1), 29-44.

Cahaya, F. R., \& Hanifa, A. (2016). Ethical communication on society issues: A story from Indonesia. Journal of Global Responsibility, 7(1), 2-17.

Cai, Y., Jo, H., \& Pan, C. (2012). Doing well while doing bad? CSR in controversial industry sectors. Journal of Business Ethics, 108(4), 467-480.

Chu, C. I., Chatterjee, B., \& Brown, A. (2012). The current status of greenhouse gas reporting by Chinese companies. Managerial Auditing Journal, 28(2), 114-139. 
Davoren, J. (2016). Three Types of Corporate Governance Mechanisms. Chron. Retrieved from http://smallbusiness.chron.com/three-types-corporate-governance-mechanisms66711.html

Deegan, C., \& Unerman, J. (2011). Financial accounting theory. Sydney: McGraw-Hill.

Dentchev, N. A. (2004). Corporate social performance as a business strategy. Journal of Business Ethics, 55(4), 395-410.

Dharmastuti, C., \& Wahyudi, S. (2013). The effectivity of internal and external corporate governance mechanisms towards corporate performance. Research Journal of Finance and Accounting, 4(4), 132-139.

Esa, E., \& Ghazali, N. A. M. (2012). Corporate social responsibility and corporate governance in Malaysian government-linked companies. International Journal of Business in Society, $12(3), 292-305$.

Franke, G. $\quad$ R. (2010). Multicollinearity. Retrieved from https://onlinelibrary.wiley.com/doi/abs/10.1002/9781444316568.wiem02066

George, D., \& Mallery, P. (2003). Frequencies in SPSS for Windows step by step: A simple guide and reference. New York: Pearson Education.

Ghazali, N. A. M. (2007). Ownership structure and corporate social responsibility disclosure: Some Malaysian evidence. International Journal of Business in Society, 7(3), 251-266.

Gillan, S. L. (2006). Recent developments in corporate governance: An overview. Journal of Corporate Finance, 12, 381-40.

Global Reporting Initiative. (2016). About sustainability reporting. Retrieved from https://www.globalreporting.org/information/sustainability-reporting/Pages/default.aspx

Guthrie, J., Cuganesan, S., \& Ward, L. (2007). Legitimacy theory: A story of reporting social and environmental matters within the Australian food and beverage industry. Paper presented at the $5^{\text {th }}$ Asian Pacific Interdisciplinary Research in Accounting (APIRA) Conference (pp. 1-35). Auckland, New Zealand.

Habbash, M. (2016). Corporate governance and corporate social responsibility disclosure: Evidence from Saudi Arabia. Social Responsibility Journal, 12(4), 740-754.

Hair, J. E., Anderson, R. E., Tatham, R. L., \& Black, W. C. (1998). Multivariate Data Analysis, (5th ed.). Upper Saddle River, NJ: Prentice-Hall.

Haniffa, R., \& Hudaib, M. (2006). Corporate governance structure and performance of Malaysian listed companies. Journal of Business Finance and Accounting, 33(7), 1034-1062.

Haniffa, R. M., \& Cooke, T. E. (2005). The impact of culture and corporate governance on corporate social reporting. Journal of Accounting and Public Policy, 24, 391-430.

Heard, J. E., \& Bolce, W. J. (1981). The political significance of corporate social reporting in the United States of America. Accounting, Organizations and Society, 6(3), 247-254.

Ho, S. S. M., \& Wong, K. S. (2001). A study of the relationship between corporate governance structures and the extent of voluntary disclosure. Journal of International Accounting, Auditing and Taxation, 10(2), 139-156.

Jensen, M. C. (1993). The modern industrial revolution, exit and the failure of internal control systems. The Journal of Finance, 48(3), 831-80.

Jizi, M. I., Salama, A., Dixon, R., \& Stratling, R. (2014). Corporate governance and corporate social responsibility disclosure: Evidence from the US banking sector. Journal of Business Ethics, 125(4), 601-615. 
Joseph, C., Gunawan, J., Sawani, Y., Rahmat, M., Noyem, J. A., \& Darus, F. (2016). A comparative study of anti-corruption practice disclosure among Malaysian and Indonesian corporate social responsibility (CSR) best practice companies. Journal of Cleaner Production, 112, 2896-2906.

Khan, A., Muttakin, M. B., \& Siddiqui, J. (2013). Corporate governance and corporate social responsibility disclosures: Evidence from an emerging economy. Journal of Business Ethics, 114(2), 207-223.

Krippendorff, K. (1989). Content analysis. Penn Libraries. Retrieved from http://repository.upenn.edu/cgi/viewcontent.cgi?article=1232\&context=asc_papers

Laan, S. V. D. (2009). The role of theory in explaining motivation for corporate social disclosures: Voluntary disclosures vs 'Solicited' disclosures. Australasian Accounting, Business and Finance Journal, 3(4), 15-29.

Lindblom, C. K. (1993). The implications of organizational legitimacy for corporate social performance and disclosure. Proceedings at the Critical Perspective on Accounting Conference, New York.

Malaysian Code on Corporate Governance. (2017). Retrieved from https://www.sc.com.my/wpcontent/uploads/eng/html/cg/mccg2017.pdf

Malaysian Institute of Corporate Governance. (2016). Institute's profile. Retrieved from http://www.micg.org.my/Static/VisionMission

Mallin, C. A. (2014). Corporate governance. Oxford University Press: New York.

Midin, M., Joseph, C., \& Mohamed, N. (2017). Promoting societal governance: stakeholders' engagement disclosure on Malaysia local authorities' websites. Journal of Cleaner Production, 142(4), 1672-1683.

NST Online. (2017, May 15). Enhancing boardroom diversity, independence. Retrieved from https://www.nst.com.my/business/2017/05/239507/enhancing-boardroom-diversityindependence

O’Donovan, G. (2002). Environmental disclosures in the annual report: Extending the applicability and predictive power of legitimacy theory. Accounting, Auditing and Accountability Journal, 15(3), 344-371.

Omran, M. A. (2015). Theoretical perspectives on corporate social responsibility disclosure: A critical review. International Journal of Accounting and Financial Reporting, 5(2), 3855.

Othman, S., Darus, F., \& Arshad, R. (2011). The influence of coercive isomorphism on corporate social responsibility reporting and reputation. Social Responsibility Journal, 7(1), 119 135.

Petrocelli, J. V. (2003). Hierarchical multiple regression in counselling research: Common problems and possible remedies. Measurement and Evaluation in Counseling and Development, 36, 9-22.

Petrovic-Lazarevic, S. (2010). Good corporate citizenship in the Australian construction industry. International Journal of Business in Society, 10(2), 115-128.

Rahman, R. A., \& Ali, F. H. M. (2006). Board, audit committee, culture and earnings management: Malaysian evidence. Managerial Auditing Journal, 21(7), 783-804.

Said, S., Zainuddin, Y. H., \& Haron, H. (2009). The relationship between corporate social responsibility disclosure and corporate governance characteristics in Malaysian public listed companies. Social Responsibility Journal, 5(2), 212-226.

Securities Commission Malaysia. (2016). Corporate responsibility. Retrieved from http://www.sc.com.my/corporate-responsibility/ 
Sman, C. (2016, May 5). Batu Danau not denied of development. The Borneo Post. Retrieved from https:/www.theborneopost.com/2016/05/05/batu-danau-not-denied-of-development/

Stuebs, M., \& Sun, L. (2015). Corporate governance and social responsibility. International Journal of Law and Management, 57(1), 38-52.

Teoh, H. Y., \& Thong, G. (1984). Another look at corporate social responsibility and reporting: An empirical study in a developing country. Accounting, Organizations and Society, 9(2), 189-206.

Thomson, L. M. (2009). What is corporate governance? The Economic Times. Retrieved from https://economictimes.indiatimes.com/money-you/what-is-corporate-governance/ articleshow/3995278.cms

Vurro, C., \& Perrini, F. (2011). Making the most of corporate social responsibility reporting: Disclosure structure and its impact on performance. International Journal of Business in Society, 11(4), 459-474.

Yekini, K. C., Adelopo, I., Andrikopoulos, P., \& Yekini, S. (2015). Impact of board independence on the quality of community disclosures in annual reports. Accounting Forum, 39(4), 249267.

Zahra, S. A., \& Pearce, J. A. (1989). Boards of directors and corporate financial performance: A review and integrative model. Journal of Management, 15(2), 291-334.

Zulkiflee, M. R. (2016). The effect of board characteristics on corporate social responsibility (CSR) disclosure. Retrieved from http://upikpolimas.edu.my/ojs/index.php/ JTVE/article/view/2/1 